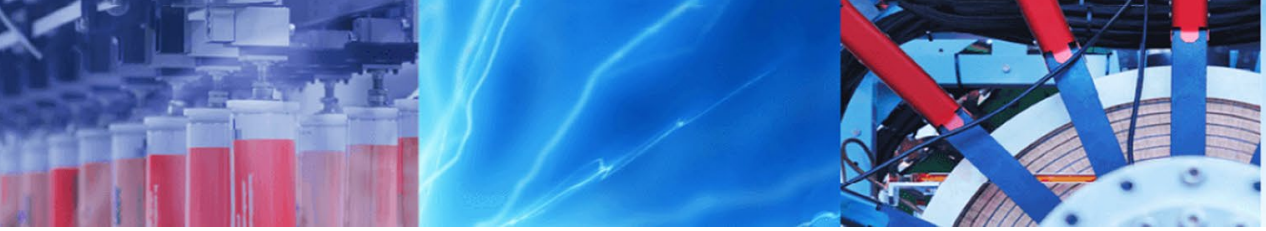

Research Article

\title{
Stability improvement of 200 MW Gabal El-Zayt wind farm connected to electrical grid using supercapacitor and static synchronous compensator during extreme gust
}

\author{
Omar Noureldeen $^{1}$ (D) Marwa M. M. Youssef ${ }^{1}$ (D) B. Hassanin ${ }^{2}$
}

(c) Springer Nature Switzerland AG 2019

\begin{abstract}
This paper proposes constant active and reactive power control of a wind farm during gust using the supercapacitor (SC) and static synchronous compensator (STATCOM). The proposed technique is applied to Gabal El-Zayt wind farm which located in Red Sea region of Egypt with a capacity of $200 \mathrm{MW}$ and equipped with doubly fed induction generators (DFIGs) and analyzed during gust wind. As the nature of wind is varying all time, the output power is changing continuously so energy storage system such as SC is required. SC is responsible for maintaining constant output active power by charging when there is excess in the output power of DFIG and discharging when there is a lack in the output power of DFIG. Reactive power compensation is achieved by connecting STATCOM to the power system. SC keeps reactive power constant however its value is improved by connecting STATCOM. Wind farm model is analyzed during gust with the proposed technique while active and reactive power performance is investigated. Firstly, the effect of connecting SC to each wind turbine is studied. Then the effect of connecting STATCOM to the electric power system is studied. Also, the effect of connecting SCs and STATCOM is studied. Finally, the impact of connecting additional STATCOM at different locations is investigated. Results show the proposed technique validity.
\end{abstract}

Keywords DFIG · Supercapacitor · Wind farm · Power system control · STATCOM · Gabal El-Zayt · ESS

\section{Introduction}

Nowadays, wind energy covers a large amount of utilized energy all over the world as it is a clean renewable energy source and available all day at different spaces. Wind turbines convert the kinetic energy (KE) of air into mechanical energy which is converted by electric generator to electric power. Wind turbines recover only a part of $K E$, this part is called power coefficient $\left(C_{p}\right)$ with a maximum theoretical value of 0.593 . The maximum value of $C_{p}$ is achieved by controlling the pitch angle and regulating the mechanical speed. Wind turbines can be classified into two types, fixed speed wind turbines (FSWTs) and variable speed wind turbines (VSWTs). VSWT can track the maximum power point by varying mechanical speed that cannot be done in FSWTs. There are different techniques used with VSWT such as full converter system that uses a permanent magnet or wound rotor synchronous generator and partial converter system that uses the doubly fed induction generator (DFIG). DFIG has both the stator and rotor windings connected to the grid however the stator connected directly, and the rotor connected through a back-to-back converter which consists of rotor side converter (RSC) and grid side converter (GSC). Due to the direct connection of the stator to the grid, DFIG is very sensitive to any disturbance occurs in the network [1, 2].

The nature of wind speed varies all time this, in turn, causes variable generated power especially if wind turbines are exposed to a gust. Pumped water and compressed air are the most commonly used energy storage

$\triangle$ Omar Noureldeen, omar_noureldeen@svu.edu.eg | 'Electrical Engineering Department, Faculty of Engineering, South Valley University, Qena 83523, Egypt. ${ }^{2}$ Electrical Engineering Department, Faculty of Engineering, Al-Azhar University, Qena, Egypt.

SN Applied Sciences (2019) 1:331 | https://doi.org/10.1007/s42452-019-0351-5

Received: 2 January 2019 / Accepted: 7 March 2019 / Published online: 12 March 2019

SN Applied Sciences

a SPRINGer Nature journal 
technologies for power grids due to their low capital costs. In [3-5] flywheel is used as energy storage to increase the stability of wind turbine. Energy storage over 10 min using, for example, flywheels allows $10 \%$ more wind energy to be absorbed without grid reinforcement and appears to be economically worthwhile. Energy storage over $24 \mathrm{~h}$ using redox flow cells allows up to $25 \%$ more wind energy to be absorbed and $30 \%$ more revenue to be earned but does not appear to be economically justified [6]. However, these technologies are heavily dependent on geographical location with relatively low round trip efficiency. Energy storage system (ESS) is required to keep constant output power as in $[7,8]$. Batteries and supercapacitor (SC) are types of ESS that have higher speed response than other traditional ESS that has mechanical parts $[9,10]$. In $[11,12]$ batteries are used with wind energy to improve response and stability. In [13] batteries are used with wind energy using fuzzy logic control. In [14, 15] batteries are used as ESS with a Wind/Photovoltaics hybrid system to compensate lack of energy is the good method to relinquish the uncertainty of the two renewable sources. In [16] batteries are used as ESS with a standalone Wind/Photovoltaics hybrid system during wind gust as the generator and battery currents are the parameters of the system that directly affected by changes in the wind speed. Compared to batteries, $\mathrm{SC}$ has a large power density that makes $\mathrm{SC}$ is more applicable in high power rating applications. SC coupled with DFIG system as it can be used to improve low voltage ride through of wind turbines during faults and also used for constant power application [8].

In wind energy application, SC is controlled through DCchopper converter such as buck-boost converter that allows flowing power in two directions and connected to DC-link capacitor [17]. In [18, 19] SC is used with power electronic converter to absorb the excess energy of wind energy system equipped with synchronous generator and full converter during the fault condition. In [20-25] SC is used to improve LVRT of wind energy system equipped with DFIG and back-to-back converter during the fault condition. However, in $[8,26-28]$, SC is used to achieve constant output power during wind speed variation. SC combined with the crowbar is used in [21] to protect the converter and improve (LVRT) capability of DFIG during grid faults. SC is used for power fluctuation suppression in [26, 28, 29]. In [30] SC is used to reduce frequency disturbance under load variation or fault occurrence. SC with enhanced field-oriented control technique is applied grid connected DFIG to improve LVRT as in [23]. SC is controlled by a fuzzy logic control to dynamically match the intermitting of wind energy and for the active power regulation as in [31]. SC also has been applied to a hybrid wind-photovoltaic system as in [32]. In [33,34] SC can be combined with batteries to operate as hybrid ESS. In [35] SC is connected to the whole wind farm at terminal bus not to individual wind turbine using a controlled rectifier. SC is connected with switch type fault current limiter to enhance LVRT where the Switch type fault current limiter effectively reduce the overcurrent in the rotor side during the fault [36]. SC can be used in a different application as in [37] the authors investigate the possible use of a commercial supercapacitor to construct a very low-frequency oscillator. The efficiency of SC is significantly high and due to the internal resistance or problems in the cooling system the efficiency may decrease, the efficiency of SC can be calculated as in [38]. In addition to the energy storage system used for active power compensation, there are also reactive power compensation sources. Flexible alternating current transmission systems (FACTS) devices are used to increase the stability of the power system by controlling network voltage magnitude or phase angle [39]. Static synchronous compensator (STATCOM) is a type of FACTS used to compensate reactive power by regulating network voltage or reactive power $[40,41]$.

STATCOM uses a three-level converter with two splitting DC capacitor is more applicable in high power application with less ripple and harmonic compared to a two-level converter which uses one DC capacitor [42]. In [43-47] SC coupled to STATCOM at DC-link capacitor is used to compensate active and reactive power, where STATCOM uses two-level converter. This paper proposes combination control for constant both active and reactive output power of wind farm (WF) during gust where STATCOM and SC are connected separately to wind energy system as STATCOM with a three-level converter is connected to the network and SC is coupled to each DFIG through DC-link capacitor. On the contrary to previous researches, this paper uses the STATCOM with a three-level converter to reduce the harmonic and using gate turn-off thyristor (GTO) which is more applicable for high power application. Also, in this paper, SC and STATCOM are connected separated to achieve separate control.

This paper is organized as follows: Sect. 2 analyzes DFIG system and Sect. 3 shows SC characteristics and model. Section 4 illustrates the ESS configuration and control. Section 5 shows the STATCOM configuration and operation. Suggested model is illustrated in Sect. 6 and the results in Sect. 7. Section 8 illustrates a discussion about the results. Section 9 illustrates the conclusion of the proposed methodology.

\section{Doubly fed induction generator system}

The construction of DFIG has the stator winding connected to the grid and the rotor winding connected to a back-to-back converter (GSC and RSC which connected through the DC-link capacitor) as shown in Fig. 1. 
As the stator winding is connected to a balanced threephase supply, the stator flux rotates with constant speed called synchronous speed $n_{s}$ and has constant magnitude. The parameters of the stator are the stator resistance $R_{s}$ and the stator leakage inductance $L_{s}$ which represents the unuseful flux generated by stator current and cannot across the air gap. The effective amount of flux that crosses the air gap between stator and rotor is represented by mutual inductance $L_{m}$. The parameters of the rotor are rotor resistance $R_{r}$ and inductance $L_{r}$, also the rotor has a parameter that represents the mechanical power $R_{r}(1-s) / s$ where $s$ is the slip speed [48].

$s=\frac{n_{s}-n_{r}}{n_{s}}$

where $n_{s}$ is synchronous speed and $\mathrm{n}_{\mathrm{r}}$ is rotor speed.

The induced torque $T$ depends on the stator flux $\lambda_{s}$ and the rotor current $i_{r}$ so by calculating the stator flux and regulating rotor current, the induced torque can be controlled.

$T=k \lambda_{s} i_{r}$

where $k$ is the proportionality constant. For the purpose of controlling the active and reactive power independently, DFIG is modeled using direct-quadrature $(d-q)$ axis component (park model). Flux equations are determined as follows:

$\lambda_{d s}=L_{s} i_{d s}+L_{m} i_{d r}$

$\lambda_{q s}=L_{s} i_{q s}+L_{m} i_{q r}$

$\lambda_{d r}=L_{r} i_{d r}+L_{m} i_{d s}$

$\lambda_{q r}=L_{r} i_{q r}+L_{m} i_{q s}$

where $\lambda_{d s}$ and $\lambda_{q s}$ are $d-q$ axis component of stator flux, $\lambda_{d r}$ and $\lambda_{q r}$ are $\mathrm{d}-\mathrm{q}$ axis component of rotor flux, $i_{d s}$ and $i_{q s}$ are $\mathrm{d}-\mathrm{q}$ axis component of stator current, $i_{d r}$ and $i_{q r}$ are $\mathrm{d}-\mathrm{q}$ axis component of rotor current. Stator and rotor voltages in $\mathrm{d}-\mathrm{q}$ model are calculated as follows:

$v_{d s}=i_{d s} R_{s}-\omega_{s} \lambda_{q s}+\frac{d \lambda_{d s}}{d t}$ $v_{q s}=i_{q s} R_{s}+\omega_{s} \lambda_{d s}+\frac{d \lambda_{d s}}{d t}$

$v_{d r}=i_{d r} R_{r}-\omega_{r} \lambda_{q r}+\frac{d \lambda_{d r}}{d t}$

$v_{q r}=i_{q r} R_{r}+\omega_{r} \lambda_{d r}+\frac{d \lambda_{d r}}{d t}$

where $v_{d s}$ and $v_{q s}$ are $\mathrm{d}$-q axis component of stator voltage, $v_{d r}$ and $v_{q r}$ are $\mathrm{d}-\mathrm{q}$ axis component of rotor voltage.

The active and reactive power generated by DFIG and transferred to the network is adjusted by controlling GSC and RSC.

The torque and power equations are given by:

$T=\frac{3}{2} p L_{m}\left(i_{d s} i_{q r}-i_{q s} i_{d r}\right)$

$P_{s}=v_{d s} i_{d s}+v_{q s} i_{q s}$

$Q_{s}=v_{q s} i_{d s}-v_{d s} i_{q s}$

where $p$ is pole pairs, $P_{s}$ and $Q_{s}$ are stator active and reactive power.

RSC tracks the maximum generated active power and control the reactive power transferred to the network through the stator. The active power is controlled by adjusting reference torque to adjust $d$ axis component of rotor current, however, $q$ axis component of rotor current is maintained at zero value to achieve zero reactive power. Reference values $d-q$ axis components of rotor voltage are calculated by adjusting $\mathrm{d}-\mathrm{q}$ axis components of rotor current.

GSC acts on controlling the reactive power transferred to the network through the back-to-back converter and this can be achieved by adjusting q-axis component of GSC-current. GSC keeps the voltage of the DC-link capacitor constant by maintaining the balance between active power flow from the rotor side $\left(P_{i n}\right)$ and active power flows to the grid side $\left(P_{o}\right)$. The energy stored $\mathrm{W}$ and the power $P_{d c}$ of the DC-link capacitor is given by:

Fig. 1 DFIG mode

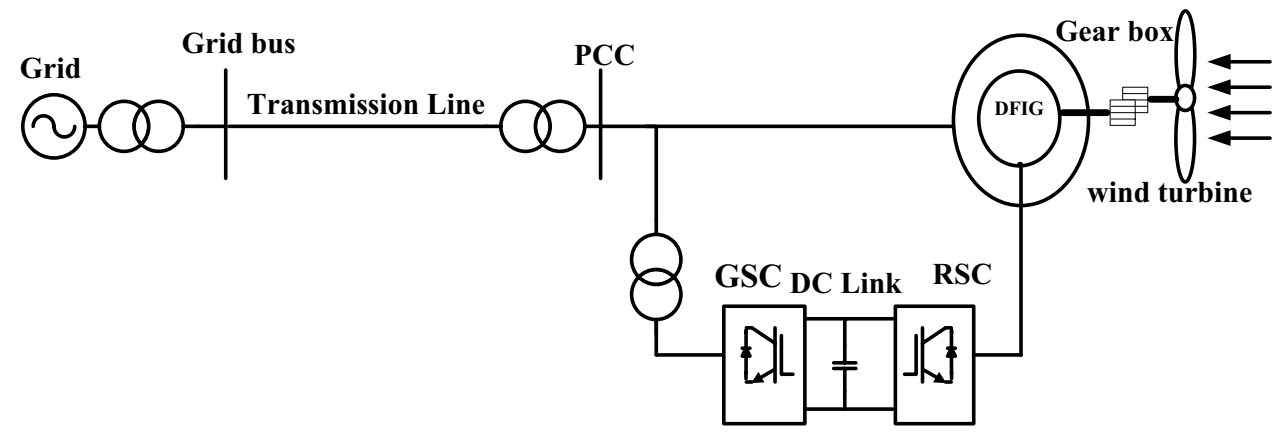

SN Applied Sciences 
$W=\int P_{d c} d t=\frac{1}{2} C_{d c} V_{d c}$

$\frac{d V_{d c}}{d t}=\frac{P_{d c}}{C_{d c} V_{d c}}, P_{d c}=P_{i n}-P_{o}$

where $C_{d c}$ is the capacity of DC-link capacitor and $V_{d c}$ is the dc-link voltage. $V_{d c}$ is kept constant when $P_{d c}$ equals zero.

\section{Supercapacitor characteristics and model}

Supercapacitor SC or (ultra-capacitor) is a type of the energy storage system which reduces the gap between conventional capacitor and batteries. SC has two parallel plates with a bigger area and a smaller distance separator than the conventional capacitor that, in turn, provides more energy to be stored and SC capacity may get to thousands of farads. SC is used in many of applications that require high stored energy as SC has many advantages such as the ability to absorb or release the energy quickly, high charging or discharging current, and long life. As shown in Fig. 2, SC is modeled by a capacitor and equivalent series resistance (ESR) which represents the internal resistance of the capacitor (the resistance of the two plates and the electrolyte) that effects the power losses in SC and equivalent parallel resistance (EPR) which represents the current leakage and affects the long-term stored energy. SC can be simply modeled by neglecting EPR.

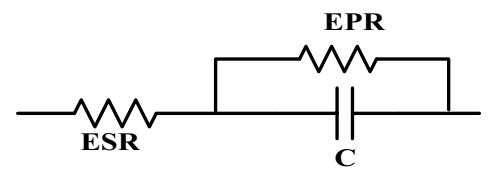

Fig. 2 SC model
The rated cell voltage of SC is low, so it is necessary to connect a large number of cells in series to get a high rated voltage that, in turn, may cause a leakage current between cells and affect the performance due to the little difference in voltage between cells resulting from the manufacture tolerance. The energy stored $\left(W_{s c}\right)$ in $\mathrm{SC}$ is calculated by Eq. (16).

$W_{s c}=\frac{1}{2} C\left(V_{\max }^{2}-V_{\min }^{2}\right)$

where $C$ is the capacity of SC. $V_{\max }$ and $V_{\min }$ is the maximum and minimum value of SC voltage. In constant power application, the capacity of SC is calculated as follows:

$W_{s c}=P t$

$C=\frac{2 P t}{V_{\max }^{2}-V_{\min }^{2}}$

where $P$ is the required power absorbed or released by SC for a certain time $(t)$.

\section{ESS configuration and control}

Supercapacitor SC is connected to the DC-link capacitor of DFIG through DC-DC converter (buck-boost) to exchange a certain amount of power as shown in Fig. 3. The DC-DC converter consists of two insulated-gates bipolar transistors (IGBTs) switches S1 and S2 each with an antiparallel diode and connected to SC through an inductor at one side and the other side connected to the DC-link capacitor. The DC-DC converter operates as a two-quadrant converter where the current can flow in the two directions that means the DC-DC converter can operate as a buck converter where $\mathrm{SC}$ is charging or operates as a boost converter where $\mathrm{SC}$ is discharging. The $\mathrm{DC}-\mathrm{DC}$ converter is controlled to maintain the output power of the DFIG constant at its reference value. This will be done by controlling the power exchanged between SC and DC-link capacitor.

Fig. 3 ESS configuration and control

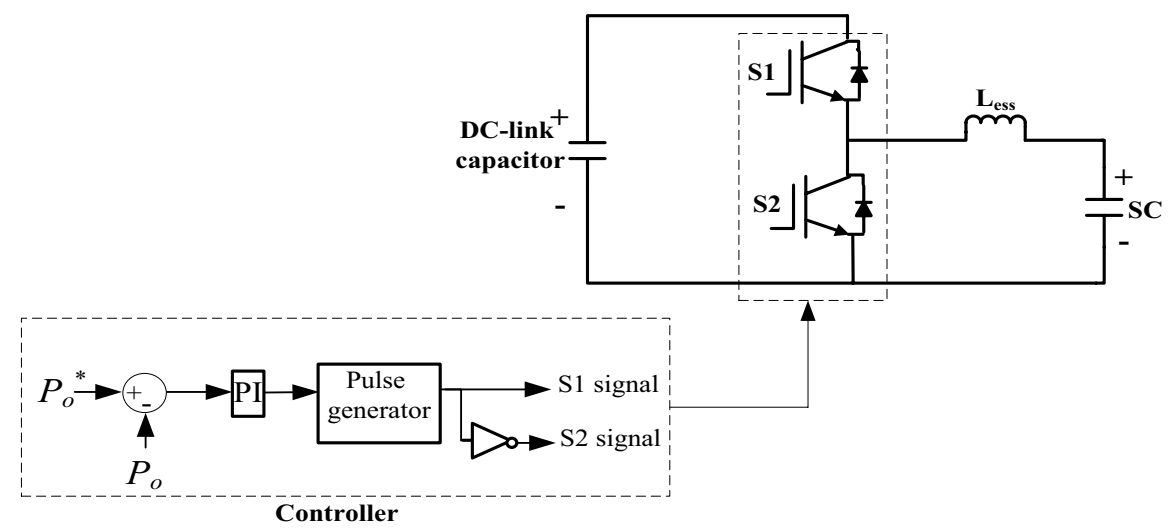


Figure 3 also shows the controller of the DC-DC converter where the output power of the DFIG is measured and compared with the reference value. The PI control is driven by the error between the measured and reference values following Eq. (19).

$K_{1}=\left(K_{p}+\frac{K_{i}}{s}\right)\left(P_{o}^{*}-P_{o}\right)$

where $K_{1}$ is the duty cycle of the switch $S 1, P_{o}^{*}$ is the reference power value, and $P_{o}$ is the output power of DFIG. $K_{p}$ and $K_{i}$ is the control parameter of PI. Considering that, the value of $P_{o}^{*}$ for different wind speeds are calculated by maximum power point tracking technique (MPPT) [15]. The output of the PI control is the duty cycle of the switches that compared with a sawtooth signal to generate the required pulses. The pulses of switch S2 is the inverse of the pulses of switch S1.

$K_{2}=1-K_{1}$

where $K_{2}$ is the required duty cycle of the switch S2.

Figure 4 shows two modes of the DC-DC converter, in mode1, operates as a buck converter where there is excess output energy from DFIG needed to be absorbed by SC so the current flows in the positive direction through the inductor and SC so the switch S1 and diode D2 operate in the first quadrant and D1 is inverse-biased. However, in mode2, the converter operates as a boost converter where there is a lack of output energy of DFIG so the current flows in the negative direction through the inductor and SC so the switch S2 and D1 operate in the second quadrant and D2 is inverse-biased.

\section{STATCOM configuration and operation}

the static synchronous compensator is a type of FACTS which is used to deliver or absorb the necessary reactive power to the power system by injecting lagging or leading current to the system to keep the voltage at rated value. Static var compensator (SVC) is also used to compensate the reactive power, however, STATCOM is more effective because the reactive power supplied is not significantly affected by the drop of network voltage which is contrary to what happens in SVC. Moreover, STATCOM has less harmonic distortion and increase network stability.

STATCOM consists of a voltage source converter (VSC) which is the main part that responsible for generating AC-voltage with less harmonic as possible, an intermediate transformer which represents an electric-coupling between VSC and the network, and DC-link capacitor which operates as a storage system for reactive power compensation as shown in Fig. 5 .

There are different topologies of STATCOM such as two-level converter which has line-to-line voltage levels $\left(0,+V_{d c}\right)$ and phase-to-neutral voltage levels $\left(0,+V_{d c} / 3\right.$, $\left.+2 V_{d c} / 3\right)$, where $V_{d c}$ is the voltage of DC-link capacitor. Multi-level converter ( $\mathrm{N}$-level) is achieved by splitting the DC capacitor to $(\mathrm{N}-1)$ capacitors to produce $\mathrm{N}$-level phase-to-neutral voltage and line voltage of $(2 \mathrm{~N}-1)$ levels. The three-level voltage converter is commonly used which consist of two splitting capacitors and control the $A C$ voltage magnitude without varying the capacitor voltage unlike the two-level converter [42].

In high power application, GTO is a more appropriate switch used with square wave operation $[49,50]$. The GTOthree level converter of 48-pulses is shown in Fig. 6 uses two converter each has 24 -pulses and shifted by $7.5^{\circ}$. The two converter is linked by four transformer with windings is phase-shifted and this interconnection helps in reducing

Fig. 5 STATCOM configuration

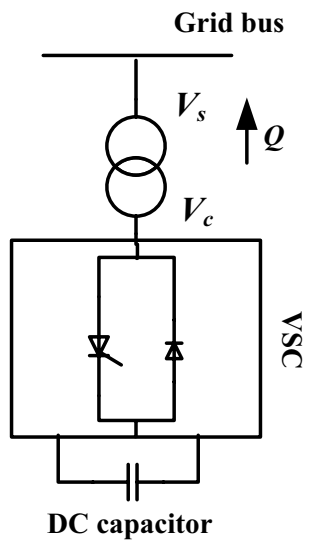

Fig. 4 Two modes of buckboost circuit

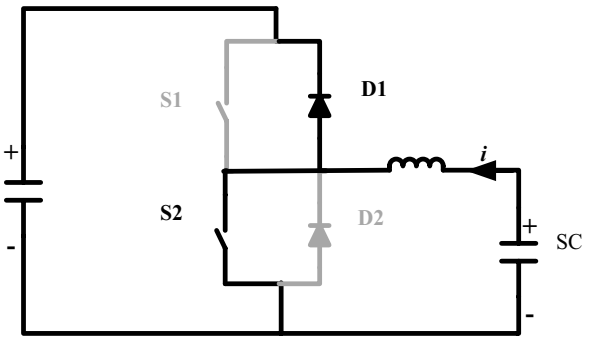

SC discharging mode

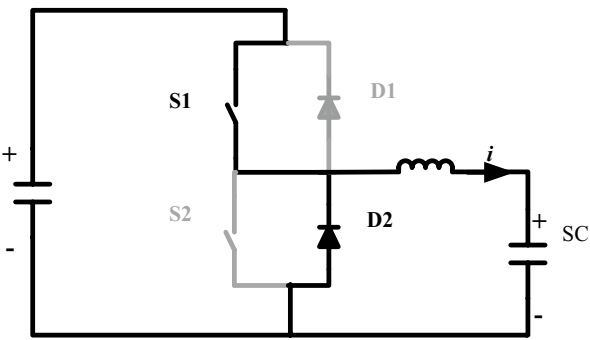

SC charging mode 
harmonics generated due to square wave operation [51, 52].

The power flow of STATCOM with the network is governed by the following equation.

$S=3\left(\frac{V_{s} V_{c}}{X_{L}}\right) \sin \alpha-j 3\left(\left(\frac{V_{s} V_{c}}{X_{L}}\right) \cos \alpha-\frac{V_{s}^{2}}{X_{L}}\right)=P-j Q$

where $S$ is the STATCOM apparent power, $P$ and $Q$ are the STATCOM active and reactive power respectively, $V_{s}$ and $V_{c}$ are voltage the network voltage and STATCOM voltage respectively, $X_{L}$ is the inductive reactance of the intermediate transformer, and $a$ is the angle between $V_{s}$ and $V_{c}$.

Active power can be controlled by changing the angle $a$ and reactive power that can be supplied by STATCOM depends on the difference between the network voltage and STATCOM voltage. To supply maximum reactive power, $a$ is set to zero to achieve zero active power however reactive power equation becomes as follows:

$Q=\frac{3 V_{s}\left(V_{c}-V_{s}\right)}{X_{L}}$
The previous equation shows that reactive power flows in the positive direction from STATCOM to the network when $V_{c}>V_{s}$ that occurs when $V_{s}$ becomes below rated value and STATCOM supplies reactive power. Reactive power flows in the negative direction from the network to STATCOM when $V_{c}<V_{s}$ that occurs when $V_{s}$ becomes overrated value and STATCOM absorbs the excess in reactive power.

However, due to the converter losses, the angle between $V_{c}$ and $V_{s}$ is adjusted to a certain value to deliver the required active power to compensate these losses rather than set at zero value.

The control of STATCOM sets the reference value of $q$-axis current component $i_{q}^{*}$ by controlling the reactive power $Q$ or controlling the network voltage $V_{s}$ to be kept at 1 pu by using PI control following Eqs. (23) or (24).

$$
\begin{aligned}
& i_{q}^{*}=\left(K_{p}+\frac{K_{i}}{s}\right)\left(V_{s}^{*}-V_{s}\right) \\
& i_{q}^{*}=\left(K_{p}+\frac{K_{i}}{s}\right)\left(Q^{*}-Q\right)
\end{aligned}
$$

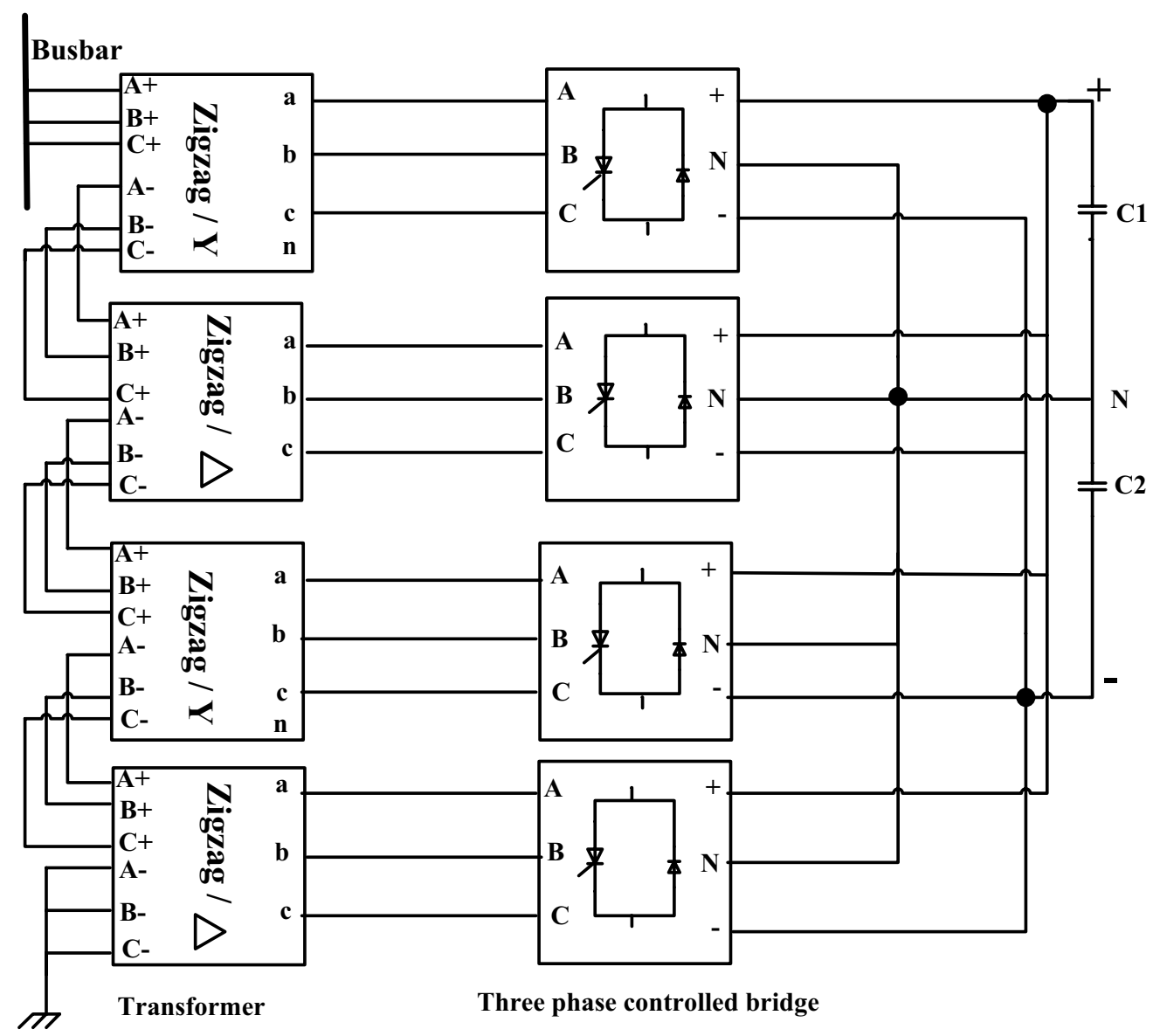

Fig. 6 GTO-three level converter with 48-pulses configuration 
Another $\mathrm{PI}$ control is driven by the error between the reference and the actual value of q-axis current and generates the required signal of converter $(\delta)$.

$\delta=\left(K_{p}+\frac{K_{i}}{s}\right)\left(i_{q}^{*}-i_{q}\right)$

\section{Configuration of suggested model}

In this paper, the suggested model is consists of WF with $200 \mathrm{MW}$ the capacity $(100 \times 2 \mathrm{MW}$ wind turbine) simulates Gabal El-Zayt WF which has four groups with capacity of (42 MW, $54 \mathrm{MW}, 52 \mathrm{MW}$, and $52 \mathrm{MW}$ ) as in [53]. Each wind turbine is coupled to DFIG with a back-to-back converter connected to SC banks through buck-boost converter. Each group is connected to bus bar (B $690 \mathrm{~V}$ ) and stepup transformer ( $T 1$ 0.69/22 kV) neglecting feeders then all groups are connected to the grid through $30 \mathrm{~km}$ transmission line and step-up transformer (T2 22/220 kV). STATCOM of $3 \mathrm{MW}$ is connected at the point of common coupling (PCC). The four groups are exposed to a gust wind for nearly $10.5 \mathrm{~s}$. The rated value of the wind speed is $15 \mathrm{~m} / \mathrm{s}$, however, the gust as simulated in [54] has a peak value wind speed $22 \mathrm{~m} / \mathrm{s}$ and assuming all groups are exposed to the gust at the same time. The suggested model is shown in Fig. 7. The design parameters of the studied model are listed in Table 1.

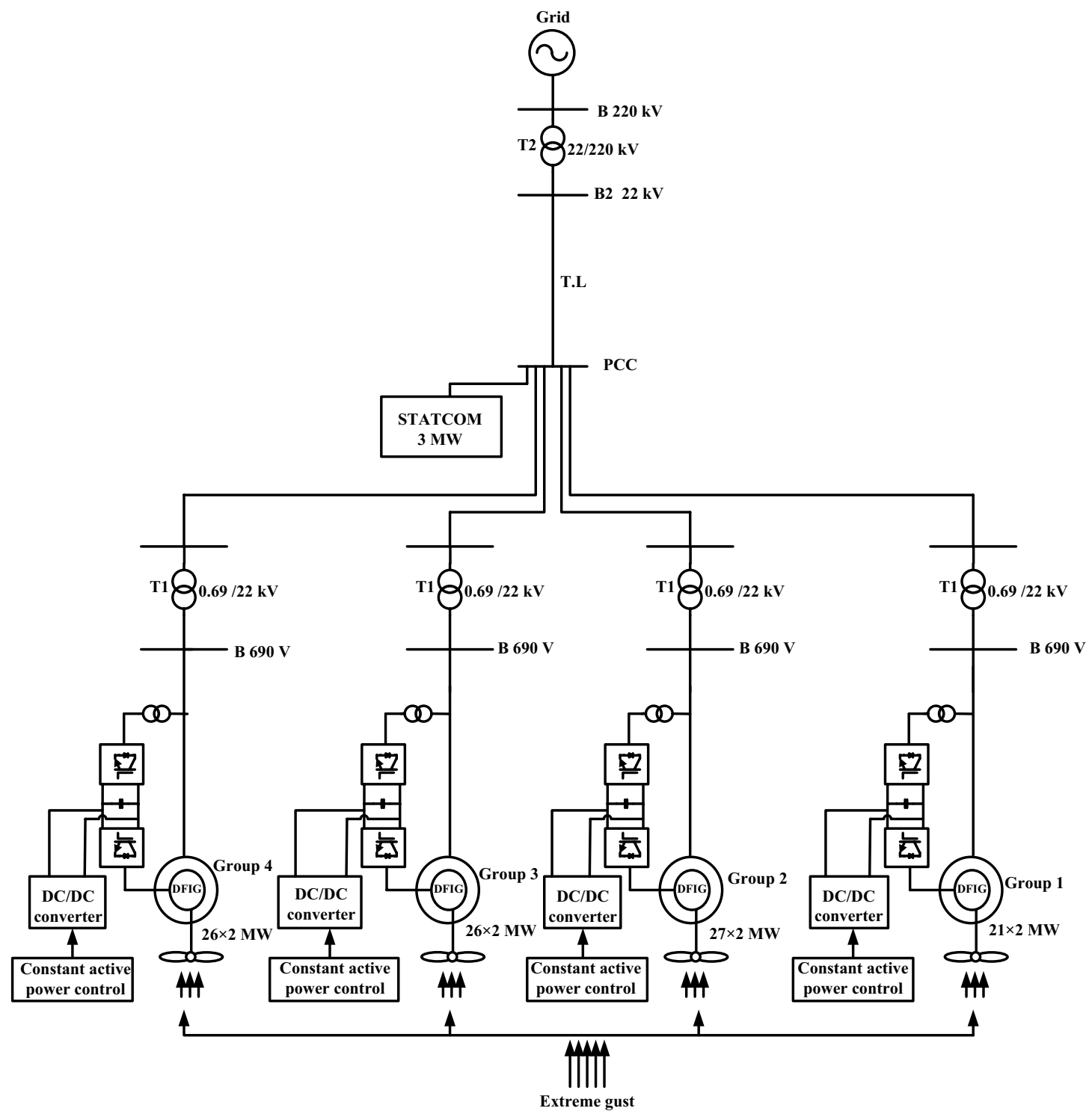

Fig. 7 Wind farm model with proposed control 
Table 1 Design parameters of studied model

\begin{tabular}{|c|c|}
\hline Parameter & Value \\
\hline \multicolumn{2}{|l|}{ DFIG parameters } \\
\hline Rated voltage & $690 \mathrm{~V}$ \\
\hline Rated power & $2 \mathrm{MW}$ \\
\hline Rotor resistance & $0.0050 \mathrm{pu}$ \\
\hline Stator resistance & $0.00706 \mathrm{pu}$ \\
\hline Mutual inductance & $2.9 \mathrm{pu}$ \\
\hline Rotor leakage inductance & $0.156 \mathrm{pu}$ \\
\hline Stator leakage inductance & $0.171 \mathrm{pu}$ \\
\hline \multicolumn{2}{|l|}{ Transmission line parameters } \\
\hline Zero sequence resistance & $0.4131 \Omega / \mathrm{km}$ \\
\hline Positive sequence resistance & $0.1154 \Omega / \mathrm{km}$ \\
\hline Zero sequence capacitance & $5.02 \mathrm{e}-9 \mathrm{~F} / \mathrm{km}$ \\
\hline Positive sequence capacitance & $11.33 \mathrm{e}-9 \mathrm{~F} / \mathrm{km}$ \\
\hline Zero sequence inductance & $0.00331 \mathrm{H} / \mathrm{km}$ \\
\hline Positive sequence inductance & $0.00105 \mathrm{H} / \mathrm{km}$ \\
\hline \multicolumn{2}{|l|}{ Transformer (T1) parameters } \\
\hline Turns ratio & $690 \mathrm{~V} / 22 \mathrm{kV}$ \\
\hline Impedance & $0.0017+\mathrm{j} 0.05 \mathrm{pu}$ \\
\hline \multicolumn{2}{|l|}{ Transformer (T2) parameters } \\
\hline Turns ratio & $22 \mathrm{kV} / 220 \mathrm{kV}$ \\
\hline Impedance & $0.00534+j 0.16 \mathrm{pu}$ \\
\hline \multicolumn{2}{|l|}{ Grid parameters } \\
\hline Impedance & $0.0004+j 0.004 \mathrm{pu}$ \\
\hline \multicolumn{2}{|l|}{ ESS parameter } \\
\hline SC capacity & $800 \mathrm{~F}$ \\
\hline DC link capacitor & $10,000 e-6 F$ \\
\hline Inductor & $10 \mathrm{mH}$ \\
\hline \multicolumn{2}{|l|}{ STATCOM parameter } \\
\hline Capacitor (C1) & $1000 \mathrm{e}-6 \mathrm{~F}$ \\
\hline Capacitor (C2) & $1000 e-6 F$ \\
\hline Primary Y zigzag nominal voltage & $25 e 3 / 4 V$ \\
\hline Secondary Y zigzag nominal voltage & $930 \mathrm{~V}$ \\
\hline Primary $\Delta$ zigzag nominal voltage & $25 e 3 / 4 V$ \\
\hline Secondary $\Delta$ zigzag nominal voltage & $930 \mathrm{~V}$ \\
\hline
\end{tabular}

\section{Simulation results}

In this section, the validity of the proposed technique is illustrated. The wind farm is exposed to the gust at $4 \mathrm{~s}$ to $14.5 \mathrm{~s}$ that has maximum value wind speed of $22 \mathrm{~m} / \mathrm{s}$ as shown in Fig. 8. The impacts of connecting SCs to each DFIG, connecting STATCOM to the grid power system, and connecting both SCS and STATCOM are investigated. Finally, a comparison between connecting additional STATCOM at different location is illustrated.

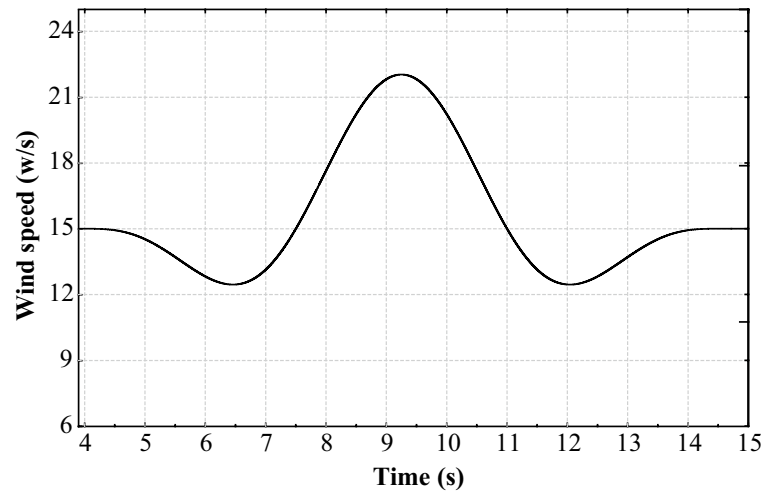

Fig. 8 Gust wind speed

\subsection{Impact of connecting SCs to each DFIG}

In this case, SC is connected to DFIG of each wind turbine. Figure 9 shows the effect of connecting SC on maintaining active and reactive power constant during gust. As shown in Fig. 9a, total active power is maintained constant at $200 \mathrm{MW}$ with SC however, it varies between 170, 240 and $137 \mathrm{MW}$ without SC. Figure $9 \mathrm{~b}$ shows that reactive power drawn from the grid is nearly kept between -10 and -11 MVAR during gust with $\mathrm{SC}$, however, varies from $-8.4,-14.4$ to -6.9 MVAR without SC. The minus sign of reactive power value means that reactive power is drawn from the grid by this value.

\subsection{Impact of connecting STATCOM to the grid power system}

In this case, STATCOM is connected to the electric grid system at PCC and the effect of STATCOM on active and reactive power is illustrated in Fig. 10. Active power is not affected by connecting STATCOM as it varies between $170-240$ and $137 \mathrm{MW}$ with and without STATCOM as shown in Fig. 10a. However, Fig. 10b shows that reactive power drawn from the grid is decreased by connecting STATCOM by nearly 1 MVAR. this deduces that STATCOM has only impact on reactive power value without affecting active power.

\subsection{Impact of connecting SCs and STATCOM}

In this case, SC is connected to each DFIG and STATCOM is connected at PCC. Figure 11 shows the effect of the gust on active power of each group with and without SC and STATCOM. Without SC and STATCOM, Fig. 11a shows that active power of the first group varies between 35.7, 50.5 and 29 MW however with SC and STATCOM, active 
Fig. 9 Measured total active and reactive power during gust with and without SC a total active power $\mathbf{b}$ reactive power measured at B2
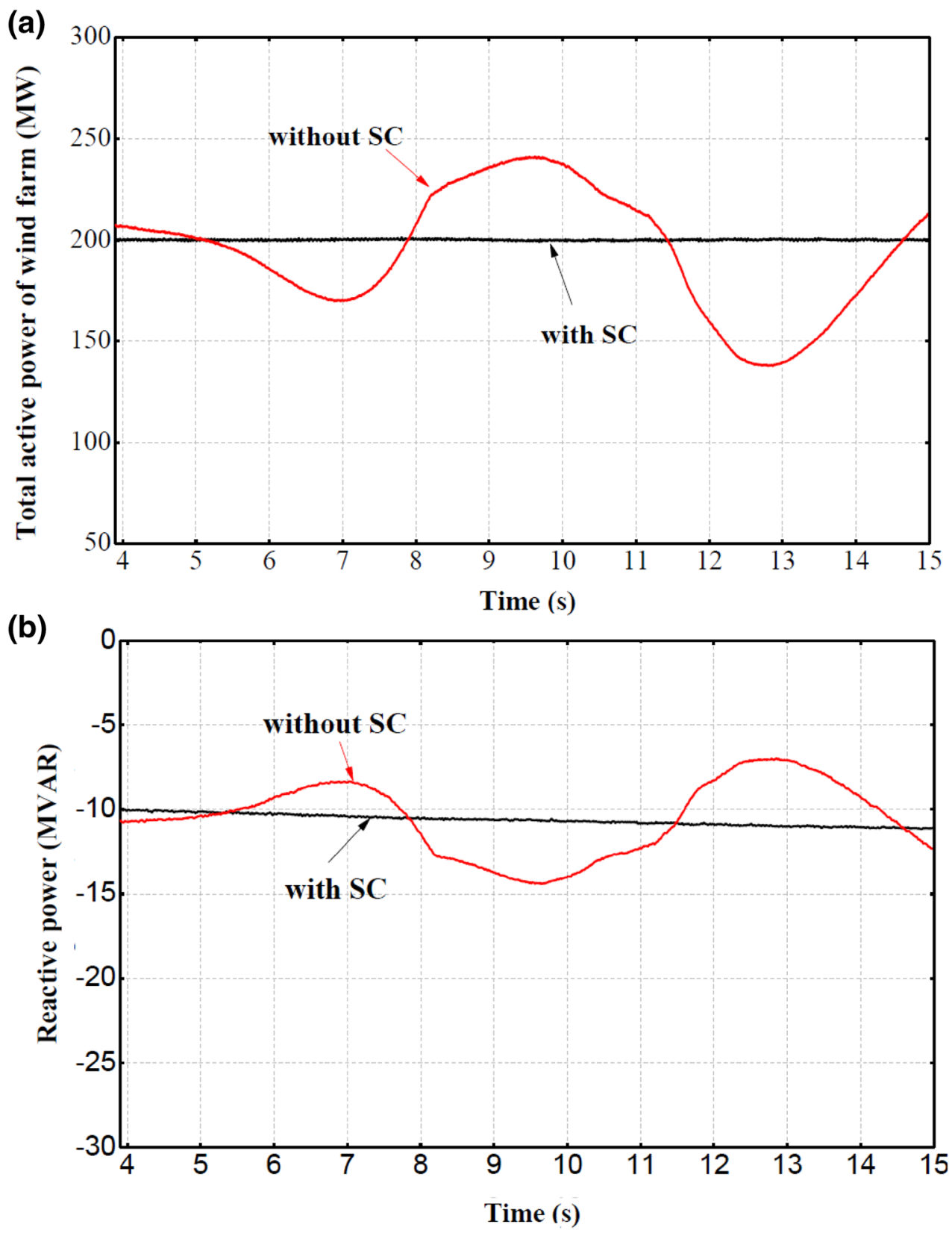

power is maintained at rated value $42 \mathrm{MW}$. Without SC and STATCOM, Fig. $11 \mathrm{~b}$ shows that active power of the second group varies between 50,65 and 37 MW however with SC and STATCOM, active power is maintained at rated value $54 \mathrm{MW}$. Without SC and STATCOM, Fig. 11c shows that active power of the third group varies between 44 , 62.5 and 36 MW however with SC and STATCOM, active power is maintained at rated value $52 \mathrm{MW}$. The fourth group fluctuates as the third group where they have the same rating of power. Total active power varies between 170, 240 and $137 \mathrm{MW}$ without SC and STATCOM however with SC and STATCOM, total active power is maintained at rated value $200 \mathrm{MW}$ as shown in Fig. 12a. Without SC and STATCOM, reactive power varies from -8.4 to -14.4 MVAR however, with SC and STATCOM, reactive power is maintained constant at -9.6 MVAR as shown in Fig. 12b. The result shows that without $\mathrm{SC}$, when wind speed increases, the active power increases and this increasing in active power is offset by decreasing in reactive power. Also, when wind speed decreases, the active power decreases and this decreasing in active power is offset by increasing in reactive power. This means whereas SC keeps the active power constant, this in turn keeps the reactive power constant. But STATCOM decrease this constant value of reactive 
Fig. 10 Measured total active and reactive power during gust with and without STATCOM a total active power $\mathbf{b}$ reactive power measured at B2
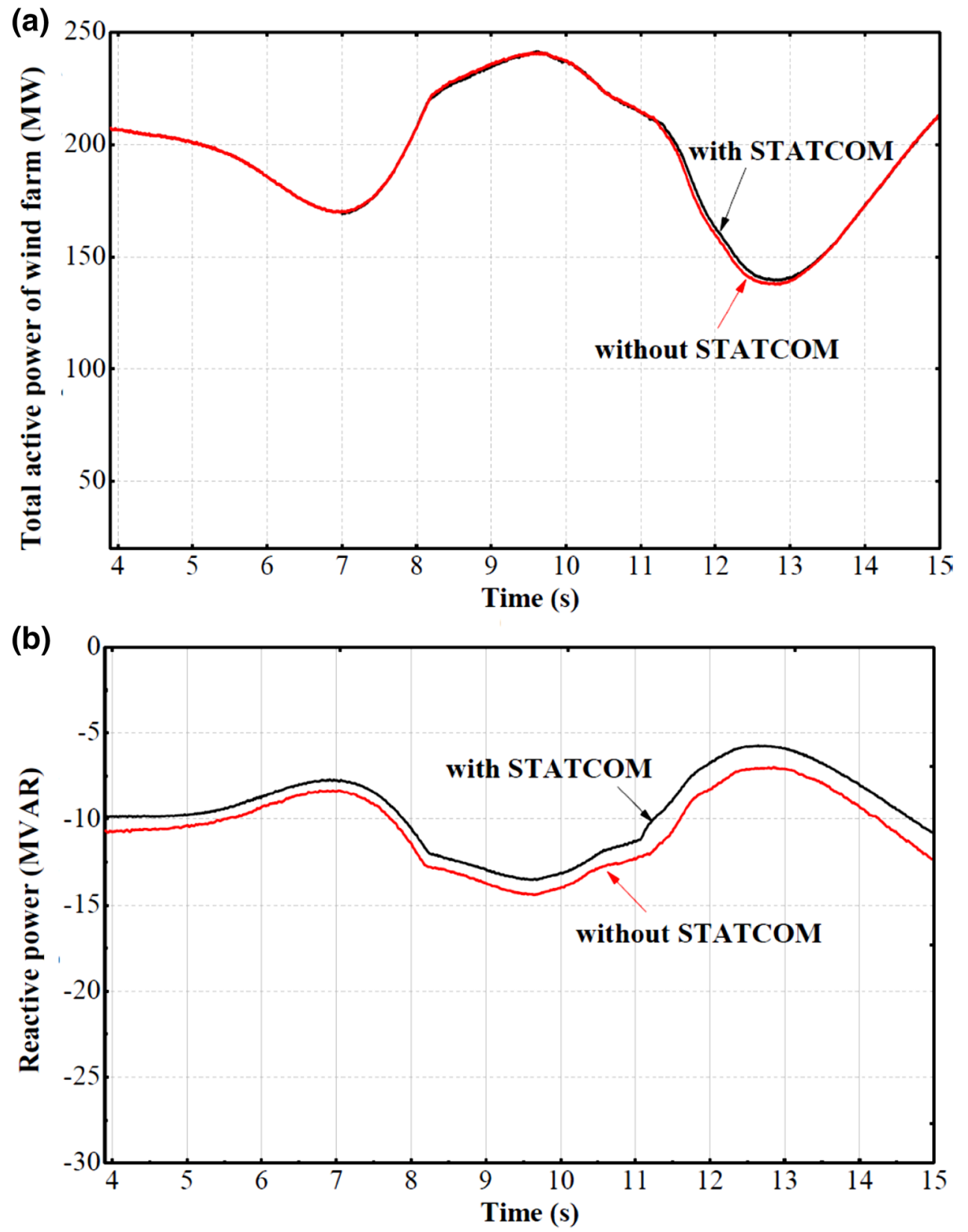

power. In other words, if STATCOM is connected without applying SC, the reactive power is decreased but still varies with wind speed variation.

\subsection{Comparison of different location of STATCOM}

For the purpose of decreasing reactive power drawn from the grid, another additional STATCOM is connected. Two positions are studied, position 1 after transmission line and position 2 at the midway distance of the transmission line, Fig. 13 shows reactive power response for each position and without STATCOM. Without SC and
STATCOM, reactive power is varying. With SC and one STATCOM at PCC, reactive power is nearly constant at 10 MVAR. By connecting additional STATCOM after transmission line at $B 2$, the reactive power drawn from the grid is decreased to 6 MVAR and the rest of reactive power is supplied by the additional STATCOM but in this case, the stress on the transmission line is the same as the case of using one STATCOM. In order to decrease the stress on the transmission line, the additional STATCOM is connected at the midway of transmission line rather than after transmission line. In this case, the reactive power drawn from the grid is decreased to 8 MVAR and 
Fig. 11 Measured active power during gust of each group with and without SC and STATCOM a first group b second group $\mathbf{c}$ third group

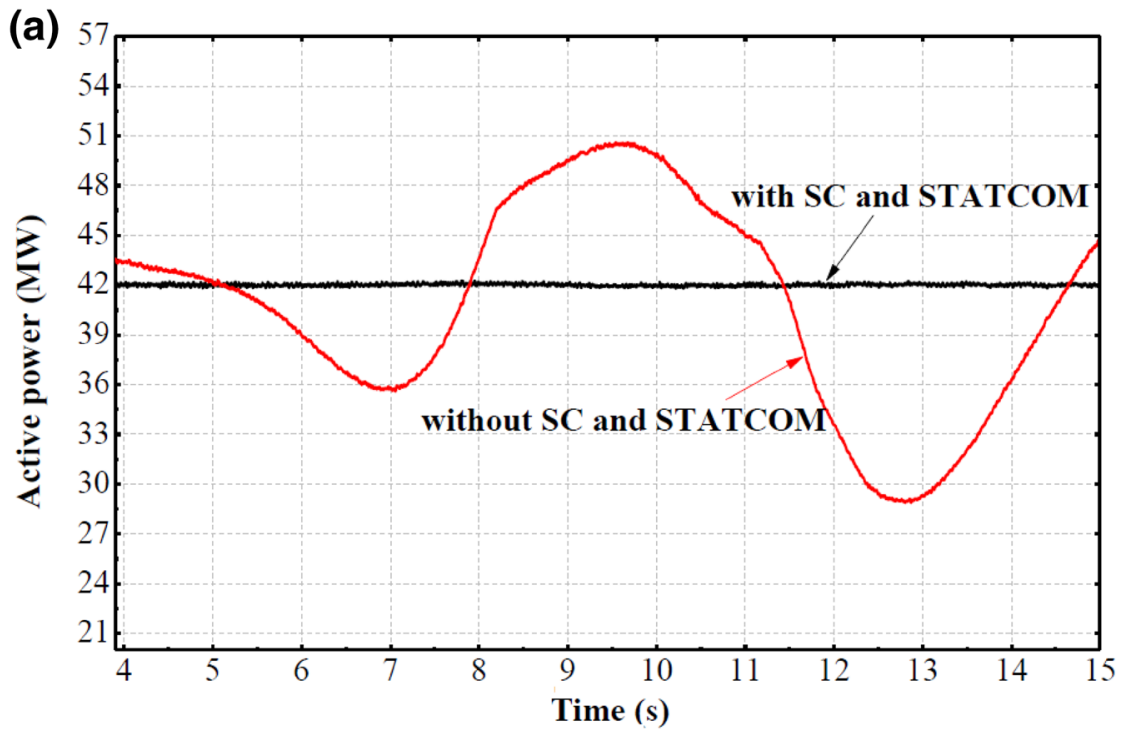

(b)
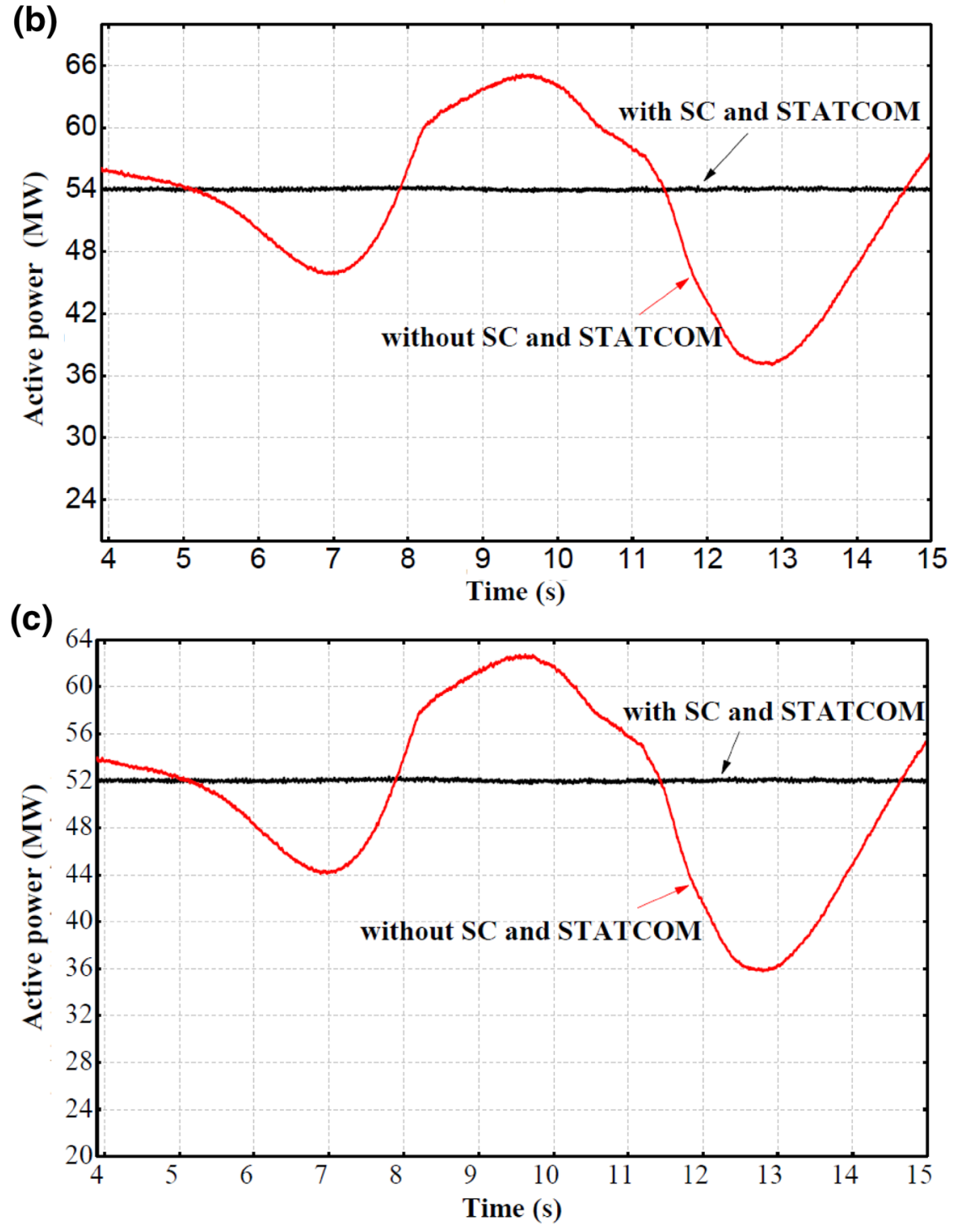
Fig. 12 Measured total active and reactive power during gust with and without SC and STATCOM a total active power b reactive power measured at B2 (a)
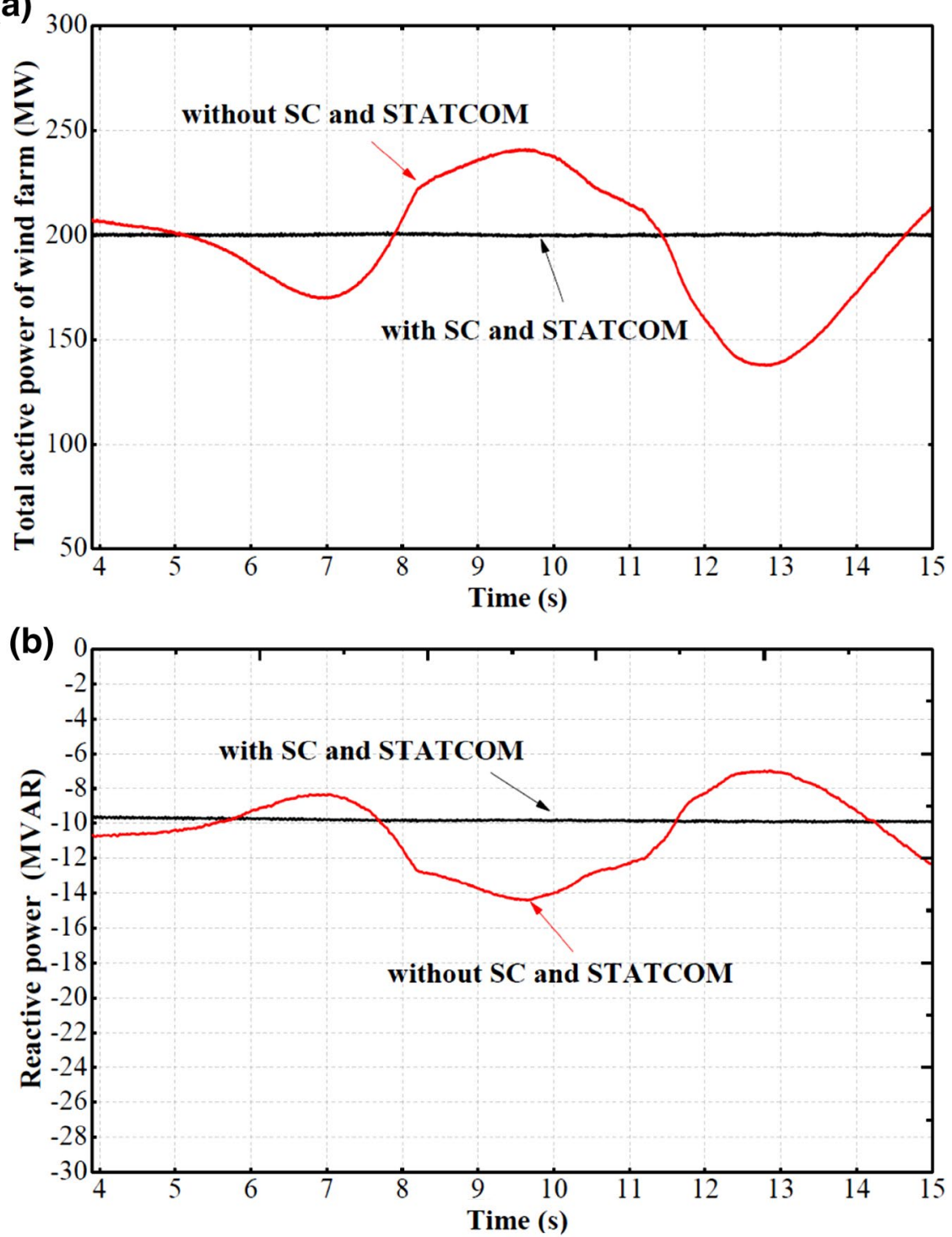

the rest of reactive power is supplied by the additional STATCOM and the stress on the half transmission line is decreased.

Finally, the results deduce that SC is responsible for maintaining active and reactive power constant, however, STATCOM specifies this constant value of reactive power without affecting active power.

\section{Discussion}

SC is connected to DC-link capacitor of DFIG through DC-DC converter. The DC-DC converter operates as a two-quadrant converter where the current can flow in the two directions to enable SC for charging and discharging. The DC-DC converter is controlled to maintain the output power of the DFIG constant at its reference value which is $2 \mathrm{MW}$ for each wind turbine. This will be done by controlling the power exchanged between SC and DC-link capacitor. As the control of SC works on keeping active power constant during wind speed variation and as the result shows that without SC, during wind speed variation, the active power varies, and also reactive power varies so connecting SC keeps the active power constant and this, in turn, keep the reactive power constant. However, in order to control this constant value of reactive power, STATCOM is required. STATCOM is connected to the electric grid system at PCC. 
Fig. 13 Measured reactive power at B2 during gust with different location of STATCOM

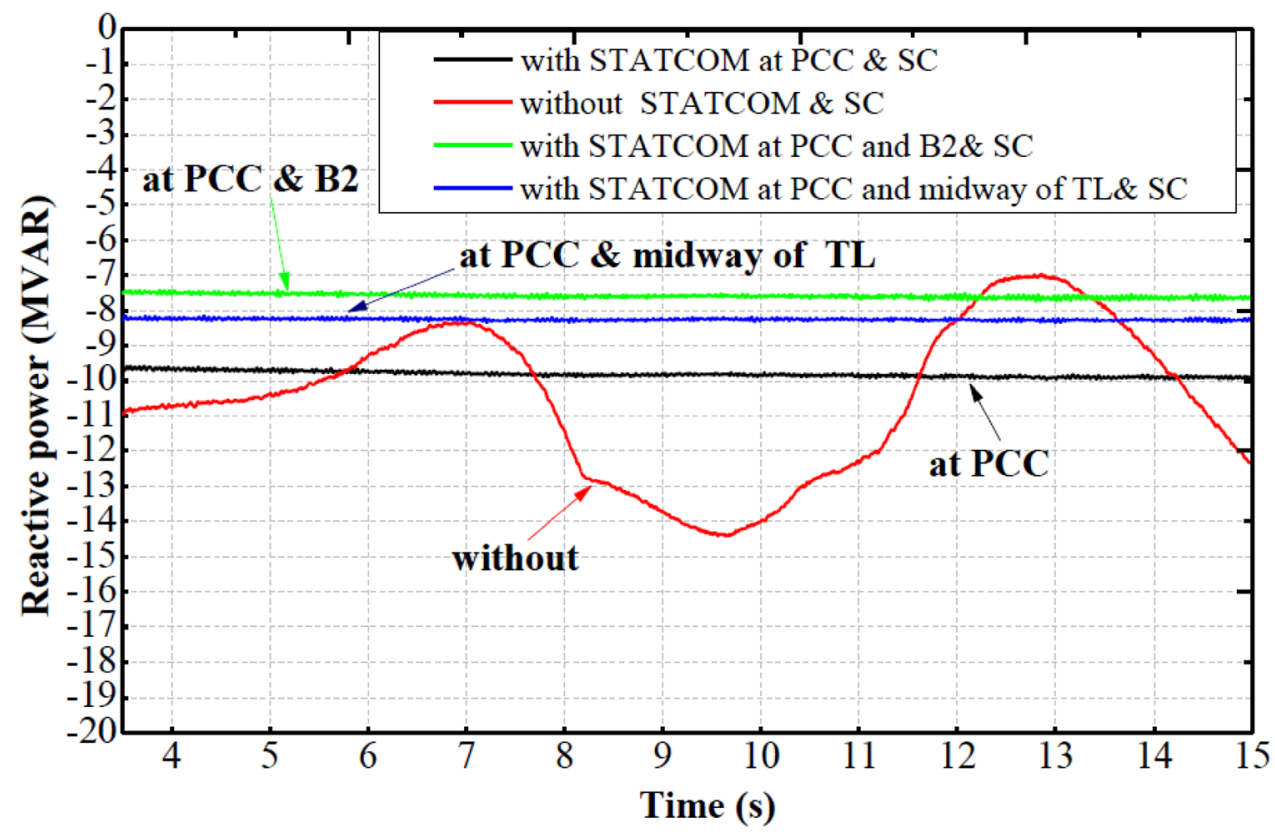

Reactive power drawn from the grid is decreased by connecting STATCOM. However, active power is not affected by connecting STATCOM. For the purpose of decreasing reactive power drawn from the grid, another additional STATCOM is connected. However, the closer STATCOM to the grid, the lower reactive power is drawn from the grid but the more stress on the transmission line. the results deduce that $\mathrm{SC}$ is responsible for maintaining active and reactive power constant, however, STATCOM specifies this constant value of reactive power without affecting active power. In other words, if STATCOM is connected without applying SC, the reactive power is decreased but still varies with wind speed variation.

\section{Conclusion}

In this paper, proposed methodology control has been suggested to achieve constant active and reactive output power of WF equipped with DFIGs during gust. Constant active power is achieved by connected SC banks through buck-boost converter to the DC-link of the back-to-back converter used with DFIG to be charging when the output power is more than reference value this means there is excess energy and discharging when the output power is less than reference value this means there is lack in energy. Reactive power compensation is achieved by connecting STATCOM to power system. $S C$ maintains reactive power constant however its value is controlled by connecting STATCOM. Result shows that output active power has been maintained at rated capacity during the gust. The impacts of connecting SCs to each DFIG are studied during the gust, total active power is maintained constant at $200 \mathrm{MW}$ with SC however, it varies between 170, 240 and $137 \mathrm{MW}$ without SC and reactive power drawn from the grid is nearly kept between - 10 and - 11 MVAR with SC however varies from $-8.4,-14.4$ to -6.9 MVAR without SC. The impacts of connecting STATCOM at PCC are studied during the gust, active power is not affected by connecting STATCOM as it varies between 170-240 and $137 \mathrm{MW}$ with and without STATCOM. However, reactive power drawn from the grid is decreased by connecting STATCOM by nearly 1 MVAR. The impacts of connecting SCs to each DFIG and STATCOM at PCC are studied during the gust, without SC and STATCOM active power of first group varies between 35.7, 50.5 and $29 \mathrm{MW}$, active power of second group varies between 50,65 and $37 \mathrm{MW}$, active power of the third group is the same as fourth group varies between 44, 62.5 and $36 \mathrm{MW}$, total active power varies between 170,240 and $137 \mathrm{MW}$, and reactive power varies from -8.4 to - 14.4 MVAR. However, with SC and STATCOM, active power is maintained at rated value $42 \mathrm{MW}, 54 \mathrm{MW}$, $52 \mathrm{MW}$, and $52 \mathrm{MW}$ for first, second, third, and fourth group respectively, total active power is maintained at rated value $200 \mathrm{MW}$, and reactive power is maintained constant at -9.6 MVAR. Reactive power is maintained constant thanks to connecting SC to each DFIG and reactive power value is compensated by connecting STATCOM. With connecting additional STATCOM, reactive power drawn from the grid decreases depending on the 
location of that additional STATCOM. However, without using SC and STATCOM, active and reactive power varies during the gust. With SC and one STATCOM at PCC, reactive power is nearly constant at 10 MVAR. By connecting additional STATCOM after transmission line at $B 2$, the reactive power drawn from the grid is decreased to 6 MVAR but in this case the stress on the transmission line is the same as the case of using one STATCOM. In order to decrease the stress on the transmission line, the additional STATCOM is connected at midway of transmission line rather than after transmission line. In this case the reactive power drawn from the grid is decreased to 8 MVAR and the stress on the half transmission line is decreased. This means that SC is responsible for maintaining active and reactive power constant, however STATCOM specify this constant value of reactive power without affecting active power.

\section{Compliance with ethical standards}

Conflict of interest The authors declare that they have no conflict of interest.

\section{References}

1. Abad G, Lopez J, Rodriguez M, Marroyo L, Iwanski G (2011) Doubly fed induction machine: modeling and control for wind energy generation, vol 85. Wiley, New York

2. Bongiorno M, Thiringer T (2013) A generic DFIG model for voltage dip ride-through analysis. IEEE Trans Energy Convers 28(1):76-85

3. Ghosh S, Kamalasadan S (2017) An energy function-based optimal control strategy for output stabilization of integrated DFIG-flywheel energy storage system. IEEE Trans Smart Grid 8(4):1922-1931

4. Hamzaoui I, Bouchafaa F, Talha A (2016) Advanced control for wind energy conversion systems with flywheel storage dedicated to improving the quality of energy. Int J Hydrog Energy 41(45):20832-20846

5. Jauch C (2015) A flywheel in a wind turbine rotor for inertia control. Wind Energy 18(9):1645-1656

6. Barton JP, Infield DG (2004) Energy storage and its use with intermittent renewable energy. IEEE Trans Energy Convers 19(2):441-448

7. Lu M-S, Chang C-L, Lee W-J, Wang L (2009) Combining the wind power generation system with energy storage equipment. IEEE Trans Ind Appl 45(6):2109-2115

8. Qu L, Qiao W (2011) Constant power control of DFIG wind turbines with supercapacitor energy storage. IEEE Trans Ind Appl 47(1):359-367

9. Vartanian C, Bentley N, Foster R (2012) Application of advanced battery energy storage systems for wind integration. In: 2012 IEEE Power and energy society general meeting. IEEE, pp 1-4

10. Takabayashi H, Sano S, Hirose Y, Mitani K, Wakatabe H (2009) The application of valve-regulated lead acid batteries to wind power generation system. In: 31 st International telecommunications energy conference, 2009. INTELEC 2009. IEEE, pp 1-5
11. Oh U, Lee Y, Choi J, Yoon Y, Chang B, Cha J-M (2016) Development of reliability contribution function of power system including wind turbine generators combined with battery energy storage system. Trans Korean Inst Electr Eng 65(3):371-381

12. Hemmati R (2017) Technical and economic analysis of home energy management system incorporating small-scale wind turbine and battery energy storage system. J Clean Prod 159:106-118

13. Meghni B, Dib D, Azar AT (2017) A second-order sliding mode and fuzzy logic control to optimal energy management in wind turbine with battery storage. Neural Comput Appl 28(6):1417-1434

14. Mousavi S, Fathi S, Riahy G (2009) Energy management of wind/ PV and battery hybrid system with consideration of memory effect in battery. In: 2009 International conference on clean electrical power. IEEE, pp 630-633

15. Vasant LG, Pawar V (2017) Optimization of solar-wind energy system power for battery charging using MPPT. In: 2017 International conference on energy, communication, data analytics and soft computing (ICECDS). IEEE, pp 1308-1310

16. Borowy BS, Salameh ZM (1997) Dynamic response of a standalone wind energy conversion system with battery energy storage to a wind gust. IEEE Trans Energy Convers 12(1):73-78

17. Wang S, Wei T, Qi Z (2008) Supercapacitor energy storage technology and its application in renewable energy power generation system. In: Proceedings of ISES world congress 2007, vol I-V. Springer, pp 2805-2809

18. Gkavanoudis SI, Demoulias CS (2012) A new fault ride-through control method for full-converter wind turbines employing supercapacitor energy storage system. In: 2012 47th International universities power engineering conference (UPEC). IEEE, pp 1-6

19. Abedi MR, Lee KY (2013) Dynamic model analysis and control of a grid connected wind energy system integrated with a supercapacitor bank. In: 2013 IEEE power and energy society general meeting. IEEE, pp 1-5

20. Haidar AM, Hagh MT, Muttaqi KM (2015) Improving low voltage ride-through using super capacitor at the DC link of doubly-fed induction generator based wind turbine. In: 2015 50th International universities power engineering conference (UPEC). IEEE, pp 1-6

21. Wang L, Wang S, Li G (2012) Improving LVRT capability of dounly fed induction generator utilizing super-capacitor with rotor crowbar protection. In: IET international conference on information science and control engineering 2012 (ICISCE 2012). IEEE, pp 1-5

22. Döşoğlu MK, Arsoy AB (2016) Transient modeling and analysis of a DFIG based wind farm with supercapacitor energy storage. Int J Electric Power Energy Syst 78:414-421

23. Duggirala VA, Gundavarapu VNK (2016) Improved LVRT for grid connected DFIG using enhanced field oriented control technique with super capacitor as external energy storage system. Eng Sci Technol Int J 19(4):1742-1752

24. Noureldeen O, Youssef MM (2018) Constant power-control of DFIG wind farm with LVRT improvement during extreme gust using super-capacitors. In: 2018 Twentieth international middle east power systems conference (MEPCON). IEEE

25. Döşoğlu MK (2017) Nonlinear dynamic modeling for fault ridethrough capability of DFIG-based wind farm. Nonlinear Dyn 89(4):2683-2694

26. Bhingare D, Virulkar V (2014) Integration of energy storage technology and wind generator for power stabilization. In: 2014 International conference on power, automation and communication (INPAC). IEEE, pp 1-5

27. Antonishen MP, Han HY, Brekken TK, von Jouanne A, Yokochi A, Halamay DA, Song J, Naviaux DB, Davidson JD, Bistrika A 
(2012) A methodology to enable wind farm participation in automatic generation control using energy storage devices. In: 2012 IEEE Power and energy society general meeting. IEEE, pp 1-7

28. Dongyang S, Xiongxin Z, Lizhi S, Fengjian W, Guangxin Z (2017) Study on power fluctuation suppression of DFIG based on super capacitor energy storage. In: 2017 IEEE conference on energy internet and energy system integration (EI2). IEEE, pp 1-6

29. Pegueroles-Queralt J, Bianchi FD, Gomis-Bellmunt O (2015) A power smoothing system based on supercapacitors for renewable distributed generation. IEEE Trans Ind Electron 62(1):343-350

30. Zhu J, Hu J, Hung W, Wang C, Zhang X, Bu S, Li Q, Urdal H, Booth CD (2018) Synthetic inertia control strategy for doubly fed induction generator wind turbine generators using lithium-ion supercapacitors. IEEE Trans Energy Convers 33(2):773-783

31. Hao X, Zhou T, Wang J, Yang X (2015) A hybrid adaptive fuzzy control strategy for DFIG-based wind turbines with super-capacitor energy storage to realize short-term grid frequency support. In: 2015 IEEE Energy conversion congress and exposition (ECCE). IEEE, pp 1914-1918

32. Tian G, Ding X, Liu J (2011) Study of control strategy for hybrid energy storage in wind-photovoltaic hybrid streetlight system. In: 2011 IEEE international workshop on open-source software for scientific computation. IEEE, pp 77-81

33. Hu X, Tseng K, Srinivasan M (2011) Optimization of battery energy storage system with super-capacitor for renewable energy applications. In: 8th International conference on power electronics-ECCE Asia. IEEE, pp 1552-1557

34. Ma T, Yang H, Lu L (2015) Development of hybrid battery-supercapacitor energy storage for remote area renewable energy systems. Appl Energy 153:56-62

35. Li X, Hu C, Liu C, Xu D (2008) Modeling and control of aggregated super-capacitor energy storage system for wind power generation. In: 2008 34th Annual conference of IEEE industrial electronics. IEEE, pp 3370-3375

36. Divya S (2015) Combination of super capacitor-switch type fault current limiter for LVRT enhancement of DFIG wind turbines. In: 2015 International conference on control communication and computing India (ICCC). IEEE, pp 343-348

37. Elwakil A, Allagui A, Maundy B, Psychalinos C (2016) A low frequency oscillator using a super-capacitor. AEU-Int J Electron Commun 70(7):970-973

38. Zhong Y, Zhang J, Li G, Liu A (2006) Research on energy efficiency of supercapacitor energy storage system. In: International conference on power system technology, 2006. PowerCon 2006. IEEE, pp 1-4

39. Haque MH (2005) Stability improvement by FACTS devices: a comparison between STATCOM and SSSC. In: IEEE Power engineering society general meeting, 2005. IEEE, pp 1708-1713

40. Mahdi Ali Abdul-Hussain SMA (2017) Static synchronous compensator (SATACOM) performance for grid-connected wind turbines. Int J Comput Appl Sci IJOCAAS 2(3):128-133

41. Noureldeen $O$, Rihan $M$, Hasanin $B$ (2011) Stability improvement of fixed speed induction generator wind farm using STATCOM during different fault locations and durations. Ain Shams Eng J 2(1):1-10
42. Singh B, Saha R, Chandra A, Al-Haddad K (2009) Static synchronous compensators (STATCOM): a review. IET Power Electron 2(4):297-324

43. Xi Z, Parkhideh B, Bhattacharya S (2008) Improving distribution system performance with integrated STATCOM and supercapacitor energy storage system. In: IEEE Power electronics specialists conference, 2008. PESC 2008. IEEE, pp 1390-1395

44. Chowdhury M, Haque M, Gargoom A, Negnevitsky M (2012) A direct drive grid connected wind energy system with STATCOM and super-capacitor energy storage. In: 2012 IEEE International conference on power system technology (POWERCON). IEEE, pp 1-6

45. Aarathi A, Jayan M (2014) Grid connected photovoltaic system with super capacitor energy storage and STATCOM for power system stability enhancement. In: 2014 International conference on advances in green energy (ICAGE). IEEE, pp 26-32

46. Bensmaine F, Bachelier O, Tnani S, Champenois G, Mouni E (2014) Modeling and control of a STATCOM-supercapacitors energy storage system associated with a wind generator. In: 2014 IEEE 23rd International symposium on industrial electronics (ISIE). IEEE, pp 156-161

47. Döşoğlu MK, Arsoy AB, Güvenç U (2017) Application of STATCOM-supercapacitor for low-voltage ride-through capability in DFIG-based wind farm. Neural Comput Appl 28(9):2665-2674

48. Fletcher J, Yang J (2010) Introduction to the doubly-fed induction generator for wind power applications. In: Paths to sustainable energy. InTech Open Access Publisher, London, pp 259-278

49. Walker LH (1988) 10 MW GTO converter for battery peaking service. In: Conference record of the 1988 IEEE industry applications society annual meeting. IEEE, pp 850-858

50. Dufour C, Bélanger J (2005) Real-time Simulation of a 48-pulse GTO STATCOM compensated power system on a dual-xeon PC using RTLAB. In: Proceedings of the 6 th international conference on power systems transients (IPST-05). Citeseer

51. El-Moursi M, Sharaf A (2005) Novel controllers for the 48-pulse VSC STATCOM and SSSC for voltage regulation and reactive power compensation. IEEE Trans Power Syst 20(4):1985-1997

52. Sahoo AK, Murugesan K, Thygarajan T (2006) Modeling and simulation of 48-pulse VSC based STATCOM using simulink's power system blockset. In: India international conference on power electronics, 2006. IICPE 2006. IEEE, pp 303-308

53. Hassan MH, Helmi D, Elshahed M, Abd-Elkhalek H (2017) Improving the capability curves of a grid-connected wind farm: Gabel El-Zeit, Egypt. In: 2017 Nineteenth international middle east power systems conference (MEPCON). IEEE, pp 300-307

54. Noureldeen O, Rashad A (2014) Modeling and investigation of Gulf El-Zayt wind farm for stability studying during extreme gust wind occurrence. Ain Shams Eng J 5(1):137-148

Publisher's Note Springer Nature remains neutral with regard to jurisdictional claims in published maps and institutional affiliations. 